\title{
Analisis Cost-of-Illness pada Pasien Hipertensi Peserta BPJS Rawat Jalan di Puskesmas Banyuanyar
}

\author{
Trias Etika ${ }^{1 *}$, Liza Pristianty ${ }^{2}$,Ika Ratna Hidayati ${ }^{3}$ \\ ${ }^{1}$ Fakultas Ilmu Kesehatan, Universitas Muhammadiyah Malang, Malang, Indonesia \\ ${ }^{2}$ Fakultas Farmasi, Universitas Airlangga, Surabaya, Indonesia
}

INFO ARTIKEL

Sejarah artikel:

Penerimaan

naskah: 27

Oktober 2020

Penerimaan

naskah revisi: 18

November 2020

Disetujui untuk

dipublikasikan:

20 November

2020

\section{Kata kunci :}

Cost-of-Illness,

Biaya Medis

Langsung, Biaya

Non-medis

Langsung, Biaya

Tidak Langsung,

Hipertensi

\section{A B S T R A K}

Hipertensi merupakan penyakit kronis yang membutuhkan terapi secara rutin untuk mengontrol tekanan darah. Pembiayaan yang dikeluarkan untuk pengobatan penyakit hipertensi dapat diukur dengan menggunakan analisis cost-of-illness. Tujuan penelitian ini adalah untuk mengetahui total biaya pengobatan pasien hipertensi peserta BPJS dengan terapi Captopril selama satu tahun untuk pengobatan rawat jalan di puskesmas Banyuanyar Kabupaten Sampang. Pada penelitian yang dilakukan oleh Baroroh dan Sari (2017) pengobatan hipertensi membutuhkan biaya yang besar karena dilakukan dalam jangka waktu yang Panjang. Metode Penelitian ini menggunakan teknik non-rondom sampling dengan metode purposive sampling dengan kriteria yang telah ditentukan oleh peneliti. Penelitian ini dilakukan di Puskesmas Banyuanyar dengan jumlah sampel pada penelitian ini sebanyak 40 orang. Instrumen yang digunakan yaitu wawancara terstruktur yang sebelumnya sudah dilakukan uji validitas isi. Data dianalisis menggunakan Microsoft ${ }^{\circledR}$ Excel. Hasil dan Kesimpulan penelitian menunjukkan bahwa cost-of-illness (biaya sakit) pada pasien hipertensi selama satu tahun yaitu sebesar Rp 36.140 sampai Rp 2.528.000. Rentang total biaya medis langsung yaitu sebesar Rp 36.140 sampai Rp 368.000 per pasien, Rentang total biaya non-medis langsung yaitu sebesar Rp 0 sampai Rp 360.000 per pasien, dan rentang total biaya tidak langsung yaitu sebesar Rp 0 sampai Rp 1.800 .000 per pasien. Adanya rentang nilai biaya yang besar dan nilai biaya yang kecil dipengaruhi frekuensi kunjungan pasien. Biaya yang lebih murah dibarengi dengan frekuensi kunjungan pasien dan kepatuhan pasien yang lebih rendah, sehingga efek terapi yang dicapai kurang baik. Sedangkan biaya yang lebih mahal, namun frekuensi kunjungan dan kepatuhan pasien lebih tinggi sehingga efek terapi yang dicapai baik dan maksimal. Efek terapi yang kurang maksimal diketahui dengan seringnya pasien membeli obat di luar puskesmas yang diakibatkan tidak terkontrolnya penyakit hipertensi sehingga dapat memicu tekanan darah sangat tinggi sewaktuwaktu, hal ini berkaitan dengan ketidakrutinan pasien dalam melakukan pengobatan di puskesmas.

\section{Cost-of-Illness Analysis in Hypertension Outpatients with BPJS (Universal Coverage) in Banyuanyar Primary Healthcare Centre}

\section{Keywords:}

Cost-of-Illness,

Direct Medical

Costs, Direct

Non-Medical

Costs, Indirect

Costs,

Hypertension

\section{A B S T R A C T}

Hypertension is a chronic disease that requires regular therapy to control blood pressure. The cost of treating hypertension can be measured by using a cost-of-illness analysis. The purpose of this study was to find out the total cost of treating hypertensive outpatients participating in BPJS (universal coverage). Who treated with Captopril for one year at the Banyuanyar primary healthcare centre in Sampang Regency. In a study by Baroroh and Sari (2017), hypertension treatment requires a large cost because it is carried out in a long time. Method this study used a non-random sampling technique with a purposive sampling method with criteria that have been determined by the researcher. This research conducted at Banyuanyar Health Center with total sample 40 people. The instrument used was a structured interview which was previously tested for content validity. The data were analyze by using Microsoft ${ }^{\circledR}$ Excel. The result of this study showed that the cost-of-illness for hypertensive patients for one year was $\mathrm{Rp} 36.140$ to $\mathrm{Rp} 2.528 .000$. The total range of direct medical costs was $\mathrm{Rp} 36.140$ to $\mathrm{Rp}$ 368.000 per patient, the range of direct non-medical costs was Rp 0 to $\mathrm{Rp} 360.000$ per patient, and the range of indirect costs is Rp. 0 to $\mathrm{Rp}$. 1.800 .000 per patient. The difference in cost value range was influenced by the frequency of patient visits. Cheaper costs indicated lower frequency of patient visits and disorderly patient compliance, therefore the therapeutic effects achieved were less good. However, more expensive cost indicated higher frequency of patient visits and orderly patient compliance, and be able to achieved better the therapeutic effects. The effect of less maximum therapy is known with often patients buying drugs outside the primary healthcare centre caused by uncontrolled hypertension disease so that it can trigger very high blood pressure at any time, this is related to the nonroutine of patients in carrying out treatment in the primary healthcare centre. 


\section{Pendahuluan}

Hipertensi atau tekanan darah tinggi merupakan peningkatan pada tekanan darah sistolik lebih dari 140 $\mathrm{mmHg}$ dan tekanan darah diastolik lebih dari $90 \mathrm{mmHg}$ dengan dua kali pengukuran pada selang waktu lima menit dalam keadaan tenang atau cukup istirahat ${ }^{1}$. Berdasarkan hasil Riset Kesehatan Dasar tahun 2018, prevalensi penyakit hipertensi dengan angka kejadian tertinggi di Indonesia yaitu pada provinsi Kalimantan Selatan sebesar $44,1 \%$, yang kemudian diikuti provinsi Jawa Barat, Kalimantan Timur, Jawa Tengah, Kalimantan Barat, dan Jawa timur. Prevalensi penyakit hipertensi terbanyak tejadi pada lansia yaitu sekitar $45,3 \%$ pada usia $45-54$ tahun, $55,2 \%$ pada usia $55-64$ tahun, $63,2 \%$ pada usia $65-74 \%$ dan $69,5 \%$ pada usia diatas 75 tahun ${ }^{2}$. Pada penelitian yang dilakukan oleh Baroroh dan Sari (2017) pengobatan hipertensi membutuhkan biaya yang besar karena dilakukan dalam jangka waktu yang Panjang ${ }^{3}$.

Lima golongan obat antihipertensi yang dikenal sebagai obat lini pertama (first line drug) yang lazim digunakan adalah ACE-inhibitor, Calcium Channel Blocker (CCB), $\beta$-bloker, Angiotensin Reseptor Blocker (ARB) dan diuretik ${ }^{4}$. Golongan obat antihipertensi yang sering digunakan dalam pengobatan hipertensi yaitu golongan ACE-inhibitor dan diuretik. Hal tersebut dikarenakan obat golongan ini dinilai paling aman dan efektif untuk menurunkan tekanan darah ${ }^{4}$. Captopril merupakan salah satu golongan ACE-inhibitor yang bekerja dengan menghambat Angiotensin Converting Enzyme (ACE), yang dalam keadaan normal bertugas mengnonaktifkan Angiotensin I menjadi Angiotensin II 5 Terdapat beberapa obat hipertensi yang masuk dalam tanggungan BPJS (Badan Penyelenggara Jaminan Sosial Kesehatan) yang diberikan kepada pasien hipertensi seperti Amlodipin, Captopril, Ramipril, Furosemid, HCT dan Bisoprolol ${ }^{6}$.

BPJS Kesehatan (Badan Penyelenggara Jaminan Sosial kesehatan) merupakan badan usaha milik negara yang ditugaskan khusus oleh pemerintah untuk menyelenggarakan dan menjamin, serta memelihara kesehatan bagi seluruh masyarakat Indonesia ${ }^{7}$. Terdapat pembiayaan kesehatan dalam BPJS yang terbagi menjadi tarif kapitasi dan tarif non-kapitasi. Pembayaran iuran terdiri dari peserta PBI (Penerima bantuan iuran) yaitu iuran yang dibayar oleh pemerintah, dan bagi peserta pekerja penerima upah yaitu iuran dibayar oleh pemberi kerja dan pekerja, dan bagi peserta bukan penerima upah dan peserta bukan pekerja yaitu iuran dibayar oleh peserta yang bersangkutan ${ }^{7}$.

Studi cost-of-illness (COI) merupakan analisis biaya suatu penyakit yang mengukur beban ekonomi penyakit dan memperkirakan jumlah maksimum yang dapat disimpan atau dihemat apabila penyakit itu bisa dicegah ${ }^{8}$. Analisis biaya atau cost-analysis merupakan metode atau cara yang digunakan untuk menghitung besarnya pengeluaran (cost atau biaya) dalam unit moneter (rupiah), baik yang langsung (direct cost) ataupun tidak langsung (indirect cost) ${ }^{9}$. Salah satu perspektif pada analisis cost-ofillness yaitu perspektif masyarakat. Perspektif masyarakat lebih disukai karena paling komprehensif dalam menganalisis semua biaya termasuk biaya medis langsung dan biaya tidak langsung sehingga memungkinkan analisis lengkap ${ }^{10}$. Salah satu peran penting studi Cost of Illness yaitu dalam diskusi kebijakan terkait biaya kesehatan masyarakat karena studi ini menganalisis besarnya biaya yang diakibatkan dari suatu penyakit di masyarakat.

Penelitian ini bertujuan untuk mengetahui total biaya pengobatan pasien hipertensi peserta BPJS dengan terapi Captopril selama satu tahun untuk pengobatan rawat jalan di puskesmas Banyuanyar Kabupaten Sampang. Menurut data Dinas Kesehatan Kabupaten Sampang tahun 2017 diperoleh bahwa kasus hipertensi sebesar 33,68\% terjadi di Puskesmas Banyuanyar Kabupaten Sampang dengan jumlah total hingga tahun 2017 yaitu sebesar 2310 pasien 11 .

\section{Metode}

Peneltian ini dilakukan dengan menggunakan metode observasional analitik dengan pendekatan cross-sectional. Pengambilan sampel pada penelitian ini menggunakan teknik non-rondom sampling dengan metode purposive sampling.

Penelitian ini telah dinyatakan laik etik oleh Komisi Etik Penelitian Kesehatan Universitas Muhammadiyah Malang berdasarkan surat kelaikan etik No.E.5.a/189/KEPK-UMM/VIII/2020. Jumlah populasi pasien hipertensi dengan terapi tunggal Captopril peserta BPJS rawat jalan di Puskesmas Banyuanyar Kabupaten Sampang yaitu sebanyak 42 orang pada bulan November 2019 hingga Januari 2020. Kemudian dari jumlah tersebut ditentukan jumlah sampel menggunakan rumus Slovin dengan tingkat kesalahan yang digunakan sebesar 5\%, sehingga didapatkan jumlah sampel pada penelitian ini yaitu sebanyak 40 responden.

Kriteria inklusi pada penelitian ini yaitu pasien hipertensi dengan usia 18 tahun ke atas ${ }^{12}$, pasien hipertensi yang menjadi peserta BPJS, pasien hipertensi rawat jalan dengan terapi tunggal Captopril, pasien yang berobat di puskesmas Banyuanyar Kabupaten Sampang, dan pasien bersedia menjadi responden.

Penelitian ini dilakukan pada tanggal 8 Agustus 2020 - 10 September 2020 di Puskesmas Banyuanyar Kecamatan Sampang Kabupaten Sampang.

Variabel pada penelitian ini yaitu data demografi pasien, biaya medis langsung, biaya non-medis langsung, dan biaya tidak langsung yang ditimbulkan dari pengobatan hipertensi di Puskesmas Banyuanyar Kabupaten Sampang.

\section{Pengumpulan Data}

Teknik pengumpulan data pada penelitian ini menggunakan wawancara terstruktur dengan empat poin utama pertanyaan. Sebelum wawancara, peneliti meminta persetujuan responden dengan mengisi informed consent. Kemudian dilanjutkan dengan wawancara.

\section{Uji Validitas}

Uji Validitas yang digunakan pada penelitian ini berupa validitas isi yaitu pengujian pada setiap butir 
Etika et al: Analisis Cost of Illness Pada Pasien Hipertensi Peserta BPJS Rawat Jalan di Puskesmas Banyuanyar ................................................43 pertanyaan pada lembar wawancara dengan ahli bidang studi yaitu dosen pembimbing.

\section{Analisis Data}

Data yang telah didokumentasikan dalam lembar wawancara di hitung, data dimasukkan kedalam program Microsoft ${ }^{\circledR}$ excel. Semua indikator biaya dari tiap variabel yang didapat dihitung dan dikalikan dengan frekuensi untuk satu tahun, lalu di buat rentang biaya tiap indikator. kemudian dijumlahkan seluruh biaya dari indikator untuk mengetahui rentang total dari setiap variable. Hasil dari total tiap variabel kemudian di jumlahkan semua mulai dari total biaya medis langsung, biaya non-medis langsung, dan biaya tidak langsung. Lalu didapatkan estimasi rentang biaya total pengobatan pasien hipertensi dengan terapi tunggal Captopril peserta BPJS rawat jalan di puskesmas Banyuanyar Kabupaten Sampang dalam satu tahun.

\section{Hasil dan Diskusi}

\section{Data Demografi Pasien}

Pasien yang memenuhi kriteria inklusi diwawancara untuk diambil data. Diperoleh 40 orang yang telah memenuhi kriteria inklusi.

Tabel 1. Data Demografi Pasien

\begin{tabular}{|c|c|c|}
\hline Data Demografi & $\begin{array}{c}\text { Jumlah } \\
\text { Responden }\end{array}$ & $\begin{array}{c}\text { Persentase } \\
(\%)\end{array}$ \\
\hline \multicolumn{3}{|l|}{ Jenis Kelamin } \\
\hline Perempuan & 29 & 72,5 \\
\hline Laki-Laki & 11 & 27,5 \\
\hline \multicolumn{3}{|l|}{ Umur } \\
\hline 18-25 tahun & 0 & 0 \\
\hline 26-45 tahun & 3 & 7,5 \\
\hline 46-65 tahun & 32 & 80 \\
\hline$>65$ tahun & 5 & 12,5 \\
\hline \multicolumn{3}{|l|}{ Tingkat Pendidikan } \\
\hline Tidak Tamat SD & 5 & 12,5 \\
\hline SD/ Sederajat & 18 & 45 \\
\hline SMP/ Sederajat & 6 & 15 \\
\hline SMA/ Sederajat & 8 & 20 \\
\hline \multicolumn{3}{|l|}{ Pekerjaan } \\
\hline Pelajar/Mahasiswa & 0 & 0 \\
\hline PNS & 1 & 2,5 \\
\hline Wiraswasta & 15 & 37,5 \\
\hline Pegawai/Buruh & 6 & 15 \\
\hline Ibu Rumah Tangga & 11 & 27,5 \\
\hline $\begin{array}{l}\text { Lainnya (Pensiun, } \\
\text { Tidak Bekerja) }\end{array}$ & 7 & 17,5 \\
\hline \multicolumn{3}{|l|}{ Pendapatan } \\
\hline \multicolumn{3}{|l|}{ Kurang dari $\mathrm{Rp}$} \\
\hline \multicolumn{3}{|l|}{$\mathrm{Rp} 1.500 .000-\mathrm{Rp}$} \\
\hline \multicolumn{3}{|l|}{$\mathrm{Rp} 2.500 .000-\mathrm{Rp}$} \\
\hline \multicolumn{3}{|l|}{ Kepesertaan BPJS } \\
\hline $\begin{array}{l}\text { Penerima Bantuan } \\
\text { Iuran (PBI) }\end{array}$ & 16 & 40 \\
\hline Kelas 1 (Bukan PBI) & 14 & 35 \\
\hline
\end{tabular}

\begin{tabular}{lll} 
Kelas 2 (Bukan PBI) & 3 & 7,5 \\
\hline Kelas 3 (Bukan PBI) & 7 & 17,5 \\
\hline
\end{tabular}

Sebagian besar responden berjenis kelamin perempuan, yaitu sebanyak 29 responden $(72,5 \%)$ dan laki-laki sebanyak 11 responden $(27,5 \%)$ (Tabel 1). Hal ini karena adanya faktor hormonal yang lebih besar terdapat pada perempuan dibandingkan dengan laki-laki, perubahan hormonal menopause dapat meningkatkan risiko penyakit degenerative seperti hipertensi. Pengaruh menopause pada tekanan darah menunjukkan bahwa pada wanita postmenopause tekanan sistolik lebih tinggi 4-5 $\mathrm{mmHg}$ dari pada wanita premenopause ${ }^{13}$.

Usia responden terbanyak yaitu 46-65 tahun sebanyak 32 responden $(80 \%)$. Hal ini dikarenakan hipertensi banyak menyerang wanita setelah umur 55 tahun dan dikaitkan dengan perubahan hormone estrogen pada wanita setelah menopause ${ }^{4}$.

Pendidikan terbanyak yaitu Sekolah Dasar (SD) yaitu sebanyak 18 responden (45\%). Hal ini sesuai dengan penelitian yang dilakukan oleh Yuwono et al (2017) mayoritas responden pasien hipertensi adalah lulusan SD artinya sebagian responden berada dalam tingkat pengetahuan yang sangat rendah, semakin tinggi tingkat pendidikan maka akan semakin baik pengetahuannya. Seseorang yang mengalami hipertensi dengan tingkat pendidikan yang sangat rendah disebabkan karena kurangnya pengetahuan tentang kesehatan maupun penyakit yang dialaminya sehingga sulit untuk mengontrol masalah kesehatannya ${ }^{14}$.

Jumlah pekerjaan terbanyak yaitu wiraswasta yaitu sebanyak 15 responden (37,5\%). Pada penelitian yang dilakukan oleh Zulfiah (2019) mayoritas responden hipertensi yang rutin melakukan pengobatan yaitu bekerja sebagai wiraswasta, pekerjaan sebagai wiraswasta memiliki waktu yang leluasa untuk melakukan pengobatan penyakitnya ${ }^{15}$.

Pendapatan terbanyak yaitu pendapatan kurang dari Rp 1.500.000 sebanyak 28 responden (70\%). Menurut penelitian yang dilakukan oleh Arif (2019) mayoritas responden yang melakukan pengobatan di puskesmas yaitu pasien dengan pendapatan dibawah Rp.1 500.000 pendapatan responden tentunya mempengaruhi pasien untuk memilih institusi pelayanan kesehatan ${ }^{16}$.

Kepesertaan BPJS terbanyak yaitu Penerima Bantuan Iuran (PBI) yaitu sebanyak 16 responden (40\%). Hasil tersebut sesuai dengan tabel 5.5 yaitu pendapatan pasien terbanyak yaitu dibawah Rp 1.500 .000 sebanyak 28 (70\%). Hal ini sesuai dengan penelitian yang dilakukan Taufiqul dkk (2017) mayoritas responden pada Fasilitas Kesehatan Tingkat Pertama (FKTP) seperti puskesmas yaitu BPJS PBI ${ }^{17}$.

\section{Biaya Medis Langsung}

Biaya medis langsung pada penelitian ini terdiri dari biaya administrasi/ pendaftaran, biaya periksa dan konsultasi (biaya jasa dokter), biaya obat antihipertensi yang didapat dari puskesmas (Captopril), dan biaya membeli obat sendiri terkait terapi hipertensi oleh pasien.

Tabel 2. Biaya Medis Langsung 
Etika et al: Analisis Cost of Illness Pada Pasien Hipertensi Peserta BPJS Rawat Jalan di Puskesmas Banyuanyar .................................................44

\begin{tabular}{|c|c|c|}
\hline $\begin{array}{l}\text { Komponen Biaya } \\
\text { Medis Langsung }\end{array}$ & $\begin{array}{c}\text { Rentang } \\
\text { Biaya Seluruh } \\
\text { Responden } \\
\text { Dalam 1 } \\
\text { Tahun }\end{array}$ & $\begin{array}{c}\text { Rentang } \\
\text { Biaya Per } \\
\text { Pasien } \\
\text { Dalam } 1 \\
\text { Tahun }\end{array}$ \\
\hline Biaya Pendaftaran & $\begin{array}{l}\mathrm{Rp} 8.000-\mathrm{Rp} \\
576.000\end{array}$ & $\begin{array}{l}\mathrm{Rp} 8.000- \\
\mathrm{Rp} 72.000\end{array}$ \\
\hline Biaya Jasa Dokter & $\begin{array}{c}\mathrm{Rp} 24.000- \\
\mathrm{Rp} 1.728 .000\end{array}$ & $\begin{array}{l}\text { Rp } 24.000 \\
-\mathrm{Rp} \\
216.000 \\
\end{array}$ \\
\hline $\begin{array}{c}\text { Biaya } \\
\text { Antihipertensi/Captopril } \\
\text { (puskesmas) }\end{array}$ & $\begin{array}{c}\mathrm{Rp} 4.140-\mathrm{Rp} \\
432.000\end{array}$ & $\begin{array}{l}\text { Rp 4.140 - } \\
\text { Rp 72.000 }\end{array}$ \\
\hline $\begin{array}{l}\text { Biaya antihipertensi } \\
\text { (membeli sendiri) }\end{array}$ & $\begin{array}{l}\mathrm{Rp} 0-\mathrm{Rp} \\
8.000\end{array}$ & $\begin{array}{l}\mathrm{Rp} 0-\mathrm{Rp} \\
8.000\end{array}$ \\
\hline $\begin{array}{l}\text { Rentang Total Biaya } \\
\text { Medis Langsung }\end{array}$ & $\begin{array}{c}\mathrm{Rp} 36.140-\mathrm{Rp} \\
2.744 .000\end{array}$ & $\begin{array}{l}\text { Rp } 36.140- \\
\operatorname{Rp} 368.000\end{array}$ \\
\hline
\end{tabular}

Pada penelitian ini didapatkan rentang total biaya medis langsung dalam 1 tahun per pasien pada tabel 2 yaitu antara Rp 36.140 sampai Rp 368.000.

Komponen biaya administrasi/ pendaftaran pasien BPJS Rawat Jalan di Puskesmas Banyuanyar Kabupaten Sampang berdasarkan tarif retribusi pelayanan kesehatan di Puskesmas Banyuanyar yaitu sebesar Rp 2.000 per pasien. Untuk total biaya pendaftaran pasien dengan frekuensi kunjungan pasien yang bervariasi dalam 1 tahun yaitu didapatkan total biaya pendaftaran per pasien dalam 1 tahun pengobatan yaitu sekitar Rp 8.000-Rp 72.000.

Komponen biaya pemeriksaan oleh dokter per pasien berdasarkan Peraturan Badan Penyelenggara Jaminan Sosial Kesehatan Nomor 2 tahun 2015, untuk biaya jasa dokter dengan rasio dokter dengan peserta BPJS yaitu $1: \leq$ 5.000 dengan waktu pelayanan 24 jam yaitu sebesar $\mathrm{Rp}$ 6.000 per pasien ${ }^{18}$. Sehingga didapatkan total biaya pendaftaran per pasien dalam 1 tahun pengobatan yaitu sekitar Rp 24.000-Rp 216.000. Adanya rentang pada biaya tersebut tergantung disebabkan karena frekuensi kunjungan pasien yang berbeda-beda.

Biaya obat antihipertensi (Captopril) yang diperoleh dari puskesmas yaitu harga obat yang dibutuhkan untuk memperoleh obat Captopril untuk pengobatan pasien hipertensi. Untuk data terkait harga obat Captopril diperoleh melalui e-catalogue. Rentang biaya obat Captopril tablet dalam 1 tahun tiap pasiennya yaitu antara Rp 4.140 sampai Rp 72.000.

Total biaya obat antihipertensi yang dibeli oleh pasien sendiri didapatkan data bahwa rentang total biaya obat antihipertensi yang dibeli pasien dalam 1 tahun per pasien yaitu sebesar Rp 0 sampai Rp 8.000. Hal ini dikarenakan pasien tersebut tidak rutin melakukan kontrol atau melakukan pengobatan penyakitnya ke puskesmas serta obat yang didapat dari puskesmas yang terbatas.

\section{Biaya Non-Medis Langsung}

Biaya non-medis langsung didapatkan bahwa dari komponen biaya perjalanan

Tabel 3. Biaya Non-Medis Langsung

\begin{tabular}{lcc}
\hline Komponen & Rentang Biaya & Rentang Biaya \\
Biaya Non- & Seluruh & Per Pasien \\
\hline
\end{tabular}

\begin{tabular}{ccc} 
Langsung & $\begin{array}{c}\text { Responden } \\
\text { Dalam 1 Tahun }\end{array}$ & Dalam 1 Tahun \\
\hline Biaya & $\mathrm{Rp} 0-\mathrm{Rp}$ & $\mathrm{Rp} \mathrm{0}-\mathrm{Rp}$ \\
Perjalanan & 360.000 & 360.000 \\
\hline
\end{tabular}

Pada biaya non-medis langsung meliputi biaya perjalanan dari rumah ke puskesmas hingga kembali ke rumah berdasarkan pada tabel 3 didapatkan biaya total perjalanan dalam 1 tahun per pasien yaitu sebesar Rp 0 hingga Rp 360.000.

Adanya rentang biaya karena jenis kendaraan bervariasi yaitu jalan kaki, sepeda, motor pribadi, kendaraan umum, becak, dan perahu. Selain itu, hal tersebut dikarenakan jarak tempuh dari rumah ke puskesmas dan frekuensi kunjungan pasien ke puskesmas yang bervariasi.

\section{Biaya Tidak Langsung}

Dalam penelitian ini tidak langsung yang diteliti adalah pendapatan pasien yang hilang karena pasien melakukan pengobatan penyakit hipertensi yang diderita dan pendapatan keluarga/ pendamping pasien yang hilang.

Tabel 4. Biaya Tidak Langsung

\begin{tabular}{ccc}
\hline $\begin{array}{c}\text { Komponen } \\
\text { Biaya Tidak } \\
\text { Langsung }\end{array}$ & $\begin{array}{c}\text { Rentang Biaya } \\
\text { Seluruh Responden } \\
\text { Dalam 1 Tahun }\end{array}$ & $\begin{array}{c}\text { Rentang } \\
\text { Biaya Per } \\
\text { Pasien Dalam } \\
\text { 1 Tahun }\end{array}$ \\
\hline $\begin{array}{c}\text { Pendapatan } \\
\text { pasien yang } \\
\text { hilang }\end{array}$ & Rp 0 - Rp 2.400.000 & $\begin{array}{c}\text { Rp 0 - Rp } \\
1.200 .000\end{array}$ \\
\hline $\begin{array}{c}\text { Pendapatan } \\
\text { keluarga }\end{array}$ & Rp 0 - Rp 600.000 & Rp 0 - Rp \\
pasien yang & & 600.000 \\
hilang & & \\
\hline Rentang & Rp 0 - Rp 3.000.000 \\
Total Biaya & & Rp 0 - Rp \\
Tidak & & 1.800 .000 \\
Langsung & & \\
\hline
\end{tabular}

Rentang total biaya tidak langsung berdasarkan tabel 4 didapatkan bahwa komponen biaya tidak langsung yaitu biaya pendapatan pasien yang hilang dan biaya pendapatan keluarga pasien yang hilang. Rentang total biaya tidak langsung per pasien dalam 1 tahun yaitu sebesar Rp 0 sampai Rp 1.800.000 dengan jenis pekerjaan yang mengalami penurunan pendapatan yaitu wiraswasta dan pegawai/buruh.

Rentang total biaya pendapatan pasien yang hilang dalam 1 tahun per pasien yaitu sebesar Rp 0 sampai Rp 1.200.000. Hal ini sesuai dengan penelitian yang dilakukan oleh Wulan tahun 2018 didapatkan bahwa biaya pendapatan pasien yang hilang untuk melakukan pengobatan yaitu dengan kisaran antara Rp 25.000 sampai Rp $900.000^{19}$. Pada rentang total biaya pendapatan keluarga pasien yang hilang dalam 1 tahun per pasien yaitu sebesar Rp 0 sampai Rp 600.000. Hal ini sesuai dengan penelitian yang dilakukan oleh Wulan tahun 2018 didapatkan bahwa biaya pendapatan keluarga pasien yang hilang untuk mengantarkan keluargnya melakukan pengobatan yaitu dengan kisaran antara Rp 20.000 sampai Rp $720.000^{19}$. jenis pekerjaan yang mengalami penurunan 
Etika et al: Analisis Cost of Illness Pada Pasien Hipertensi Peserta BPJS Rawat Jalan di Puskesmas Banyuanyar .....................................................45 pendapatan yaitu wiraswasta dan pegawai/buruh.

\section{Total Biaya Pengobatan ( Cost-of-Illness)}

Total Biaya Pengobatan / cost-of-Illness merupakan estimasi biaya yang ditimbulkan karena suatu penyakit tertentu. Pada penelitian ini, terdapat 3 variabel dari costof-illness yaitu biaya medis langsung, biaya non-medis langsung, dan biaya tidak langsung. Total estimasi biaya pengobatan / cost-of-illness dalam 1 tahun didapat dari penjumlahan 3 variabel tersebut.

Tabel 5. Total Cost-of-Illness

\begin{tabular}{ccc}
\hline $\begin{array}{c}\text { Komponen } \\
\text { Biaya }\end{array}$ & $\begin{array}{c}\text { Rentang Biaya } \\
\text { Seluruh } \\
\text { Responden } \\
\text { Dalam 1 Tahun }\end{array}$ & $\begin{array}{c}\text { Rentang } \\
\text { Biaya Per } \\
\text { Pasien Dalam } \\
\text { 1 Tahun }\end{array}$ \\
\hline Biaya Medis & Rp 36.140- Rp & Rp 36.140- Rp \\
Langsung & 2.744 .000 & 368.000 \\
\hline Biaya Non- & $\mathrm{Rp} \mathrm{0} \mathrm{-} \mathrm{Rp} \mathrm{360.000}$ & $\mathrm{Rp} \mathrm{0} \mathrm{-} \mathrm{Rp}$ \\
Medis Langsung & & 360.000 \\
\hline Biaya Tidak & $\mathrm{Rp} \mathrm{0} \mathrm{-} \mathrm{Rp}$ & $\mathrm{Rp} \mathrm{0-Rp}$ \\
Langsung & 3.000 .000 & 1.800 .000 \\
\hline Rentang Total & $\mathrm{Rp} \mathrm{36.140-Rp}$ & $\mathrm{Rp} \mathrm{36.140-}$ \\
Cost-of-Illness & 6.104 .000 & $\mathrm{Rp} \mathrm{2.528.000}$ \\
\hline
\end{tabular}

Berdasarkan pada tabel 5 didapatkan estimasi rentang biaya total pengobatan pasien hipetensi rawat jalan selama 1 tahun di puskesmas Banyuanyar Kabupaten Sampang per pasien yaitu sebesar Rp 36.140 - Rp 2.528.000.

Pada penelitian ini menunjukkan biaya tidak langsung lebih besar dibandingkan biaya langsung. Hal ini sesuai dengan penelitian yang dilakukan oleh Istiqomah dan Rochmah tahun 2016 tentang beban ekonomi pada penderita hipertensi dengan status PBI JKN di Kabupaten Pamekasan menyatakan bahwa biaya tidak langsung lebih besar dibandingkan dengan biaya langsung ${ }^{20}$. Namun penelitian ini tidak sesuai dengan penelitian yang dilakukan oleh Sari tahun 2017 tentang analisis biaya akibat sakit serta kualitas hidup pasien diabetes mellitus tipe 2 dengan penyakit jantung menyatakan bahwa biaya langsung lebih besar dibandingkan dengan biaya tidak langsung 21 .

Rentang biaya yang didapatkan yaitu dari total biaya tiap kunjungan per pasien saat melakukan pengobatan di Puskesmas dalam satu tahun, kemudian rentang biaya terendah didapatkan dari nilai biaya terkecil dari seluruh pasien, sedangkan biaya terbesar didapatkan dari nilai biaya tertinggi dari seluruh pasien. Rentang biaya yang kemudian di besar cost-of-illness terjadi karena faktor kunjungan pasien yang rutin untuk melakukan pengobatan ke Puskesmas, sedangkan rentang biaya terendah cost-ofillness terjadi karena faktor kunjungan pasien yang tidak rutin untuk melakukan pengobatan ke Puskesmas dan jumlah obat yang didapat dari puskesmas yang terbatas. Dari segi biaya dengan nilai rentang yang kecil lebih murah, namun dengan efek terapi yang kurang maksimal. Sedangkan rentang biaya yang besar lebih mahal, namun efek terapinya lebih bagus dan maksimal.

Berdasarkan hasil penelitian pada biaya medis langsung tidak sepenuhnya ditanggung oleh pasien. Pada komponen biaya pendaftaran, biaya jasa dokter, dan biaya obat yang didapat dari puskesmas ditanggung oleh BPJS. Dengan demikian, apabila pasien melakukan pengobatan secara rutin tentunya dapat mengurangi biaya tambahan untuk membeli obat sendiri, biaya transportasi untuk membeli obat sendiri, serta mendapatkan efek terapi yang maksimal. Sehingga memaksimalkan program BPJS dalam membantu meringankan beban ekonomi pasien dalam menjalankan terapi pengobatan. Pasien yang rutin melakukan pengobatan memiliki biaya yang besar dikarenakan biaya transportasi yang dikeluarkan cukup besar sehingga biaya yang dikeluarkan oleh pasien lebih besar. Sedangkan pasien yang tidak rutin melakukan pengobatan di puskesmas memiliki biaya yang lebih rendah dikarenakan jarak dari rumah yang cukup jauh dan rendahnya pendidikan pasien menyebabkan kesadaran pasien terhadap kesehatannya rendah. Pasien yang tidak patuh melakukan pengobatan dapat menyebabkan kondisi kesehatan pasien turun sewaktu-waktu sehingga pasien perlu membeli obat captopril di luar puskesmas yang menyebabkan biaya yang dikeluarkan semakin besar, baik dari faktor transportasi ke apotek maupun waktu. Pembelian obat sendiri dapat menyebabkan kesalahan pada pengobatan. Penelitian ini fokus terhadap pada pasien hipertensi tanpa komplikasi.

Berdasarkan hasil penelitian analisis cost-of-illness pada pasien hipertensi peserta BPJS rawat jalan di Puskesmas Banyuanyar Kabupaten Sampang dapat disimpulkan bahwa rentang total biaya pengobatan/ costof-illness pada pasien hipertensi dengan terapi tunggal Captopril peserta BPJS rawat jalan di Puskesmas dalam 1 tahun yaitu sebesar Rp 36.140 sampai Rp 2.528.000 per pasien. Sedangkan rentang total biaya medis langsung dalam 1 tahun yaitu sebesar Rp 36.140 sampai Rp 368.000 per pasien, rentang total biaya non-medis langsung dalam 1 tahun yaitu yaitu sebesar Rp 0 sampai Rp 360.000 per pasien, dan rentang total biaya tidak langsung dalam 1 tahun yaitu yaitu sebesar Rp 0 sampai Rp 1.800.000 per pasien.

\section{Daftar Pustaka}

1. Kemenkes. Hipertensi. Infodatin Pus. dan Inf. Kementeri. Kesehat. RI $\quad 1-7 \quad$ (2014) doi:10.1177/109019817400200403.

2. Riskesdas 2018. HASIL UTAMA RISKESDAS 2018 Kesehatan. 20-21 (2018).

3. Baroroh, F. \& Sari, A. Cost Effectiveness Analysis Therapy Combination of Candesartan-Amlodipine and Candesartan-Diltiazem on Hypertensive Outpatients. Pharm. J. Farm. Indones. (Pharmaceutical J. Indones. 14, 188-198. p-ISSN 1693-3591; e-ISSN 2579-910X (2017).

4. Pratiwi, D. Gambaran pengetahuan Pasien Hipertensi terhadap Penyakit Hipertensi dan Obat Antihipertensi Golongan ACE-Inhibitor dan Diuretik. I, 40-48 (2017).

5. Khoiriyah, S. D. \& Lestari, K. Review Artikel: Kajian Farmakoekonomi yang Mendasari Pemilihan Pengobatan di Indonesia. Farmaka 6, 134-145 (2018).

6. Hapsari, W. S. \& Agusta, H. F. Pola Penggunaan Obat 
Etika et al: Analisis Cost of Illness Pada Pasien Hipertensi Peserta BPJS Rawat Jalan di Puskesmas Banyuanyar .....................................................46

Antihipertensi Pada Pasien Hipertensi Rawat Jalan Bpjs Di Rsud Krt Setjonegoro Wonosobo. J. Farm. Sains dan Prakt. 3, 24-28 (2017).

7. Suryani, A. I. \& Suharyanto, A. Implementasi Program Badan Penyelenggara Jaminan Kesehatan (BPJS) Dalam Meningkatkan Pelayanan Administrasi Kesehatan di Rumah Sakit Umum Sibuhuan. Publikauma J. Adm. Publik Univ. Medan Area 4, 8699 (2016).

8. Purbaningsih, S., Wahyono, D. \& Suparniati, E. Cost of illness pasien stroke. J. Manag. Pharm. Pract. 5, 95-103. p-ISSN: 2088-8139, e-ISSN: 2443-2946 (2015).

9. Baroroh, F., Solikah, W. Y. \& Urfiyya, Q. A. Analisis biaya terapi Diabetes Melitus tipe 2 Di Rumah Sakit Pku Muhammadiyah Bantul Yogyakarta. J. Farm. Sains dan Prakt. I, 11-22 (2016).

10. Jo, C. Cost-of-illness studies : concepts, scopes, and methods. 327-337

(2014) doi:http://dx.doi.org/10.3350/cmh.2014.20.4.327.

11. Dinas Kesehatan Sampang. Profil Dinas Kesehatan Kabupaten Sampang Tahun 2017. (2017).

12. WHO. Part II: Global health indicators. World Heal. Stat. 2015 39-160 (2015).

13. Tandililing, S., Mukaddas, A. \& Faustine, I. Profil Penggunaan Obat Pasien Hipertensi Esensialdi Instalasi Rawat Jalan Rumah Sakit Umum Daerah I Lagaligo Kabupaten Luwu Timur Periode JanuariDesember Tahun 2014. Galen. J. Pharm. 3, 49-56. ISSN : 2442-8744 (2017).

14. Yuwono, G. A., Ridwan, M. \& Hamafi, M. Pengaruh Pendidikan Kesehatan Tentang Hipertensi Terhadap Tingkat Kecemasan Pada Penderita Hipertensi di Kabupaten Magelang. J. Keperawatan Soedirman (The Soedirman J. Nursing) 12, 55-66 (2017).

15. Zulfiah. Tingkat Kepuasan Pasien Terhadap Pelayanan Informasi Obat Hipertensi (Amlodipine $5 \mathrm{Mg}$ ) di Klinik Nur Ichsan Tahun 2019. J. Farm. Sandi Karsa 5, 105-109 (2019).

16. Arif, D. Studi Pola Keterjangkauan Puskesmas di Kabupaten Lamongan. 1, 1-7. ISSN : 2302-142X (2019).

17. Taufiqul et al. Gambaran Pemanfaatan Fasilitas Kesehatan Tingkat Pertama (FKTP) Pada Peserta Penerima Bantuan Iuran (PBI) Dan Non-Penerima Bantuan Iuran (Non-PBI) di Puskesmas Medan Denai. Ibnu Sina Biomedika 1, 154-160 (2017).

18. Peraturan BPJS Kesehatan No.2. Peraturan Badan Penyelenggara Jaminan Sosial Kesehatan Nomor 2 Tahun 2015 tentang norma penetapan besaran kapitasi dan pembayaran kapitasi berbasis pemenuhan komitmen pelayanan pada fasilitas kesehatan tingkat pertama. 39, 561-563 (2015).

19. Wulan, S. Pengeluaran Kesehatan Karena Penyakit Tuberculosis Di Kota Bengkulu. 7, 135-142 (2018).

20. Istiqomah, A. N. \& Rochmah, T. N. Beban Ekonomi Pada Penderita Hipertensi Dengan Status PBI JKN Di Kabupaten Pamekasan. J. Manaj. Kesehat. STIKES Yayasan RS.Dr. Soetomo, 2, 124-132 (2016).

21. Sari, L. S. Analisis Biaya Akibat Sakit serta Kualitas
Hidup Pasien Diabetes Mellitus Tipe 2 dengan Penyakit Jantung. J. Ekon. Kesehat. Indones. 1, 126131 (2017). 